\title{
Lawgivers, Virtue, and the Mixed Regime: Reflections on Richard Bodéüs's The Political Dimensions of Aristotle's Ethics
}

KEVIN CHERRY University of Richmond

ABSTRACT: In this paper, I engage with the works of Richard Bodéüs about Aristotle's understanding of the relationship between law, virtue, and education. I argue that there is an important difference between the demands of the law and those of reason, especially in the defective, but more common, regimes. This difference is also found in the best regime possible for most cities, the mixed regime Aristotle calls 'polity' (or, in Greek, politeia), insofar as it represents a balance between oligarchy and democracy. To educate citizens in this regime requires what Aristotle calls "political philosophy."

RÉSUMÉ : Dans cet article, je considère les travaux de Richard Bodéüs qui traitent de la manière dont Aristote envisage la relation entre loi, vertu, et éducation. Je soutiens qu'il y a une différence importante entre les exigences de la loi et celles de la raison, en particulier dans les régimes défectueux, qui sont aussi les plus communs. Cette différence existe aussi dans le meilleur régime possible pour la plupart des cités, le régime mixte qu'Aristote nomme «politie» (ou, en grec, politeia), parce qu'il représente un mélange d'oligarchie et de démocratie. Dans ce régime, éduquer les citoyens exige ce qu'Aristote appelle la philosophie politique.

Keywords: Aristotle, education, law, polity, virtue, Richard Bodéüs

Dialogue 59 (2020), 31-50

(C) Canadian Philosophical Association/Association canadienne de philosophie 2020 doi:10.1017/S0012217319000325 


\section{Introduction}

Richard Bodéüs's marvelous book The Political Dimensions of Aristotle's Ethics was originally published (albeit with a different title) in French in 1982. ${ }^{1}$ The English translation by Jan Garrett, which appeared 11 years later, was one of the first books I read in graduate school; its central argument — that there is a connection between Aristotle's ethical and political thought — influenced me significantly. The concluding chapter of the Nicomachean Ethics, Bodéüs wrote, "was meant to introduce, not necessarily the Politics as we have it, but an investigation into laws and, more generally, into constitutions" $(P D A E, 47) .^{2}$ In this article, I first summarize the argument he gives in support of this conclusion and then raise some questions about the practical consequences of this argument, in part by engaging with a book chapter published around the same time as the translation. ${ }^{3}$ Although Bodéüs argues that the purpose of Aristotle's political discourses is to enable a lawgiver to educate citizens, I suggest that — at least in most existing regimes - the lawgiver's role is to develop regimes that are stable and so allow individuals to develop virtue outside of the political realm. This is especially true in the mixed regime called 'polity' that is often considered to be the best regime generally possible. To that end, I conclude by discussing the role of, not the lawgiver, but the political philosopher in solving the problems characteristic of political life.

\section{Aristotle's Audience and Purpose}

The core argument of The Political Dimension of Aristotle's Ethics is that Aristotle offers us a single political teaching that has two parts, corresponding roughly to the Nicomachean Ethics and the Politics, which are intimately

1 Bodéüs, Le Philosophe et la Cité (Paris : Les Belles Lettres, 1982). I have occasionally referred to the electronic version of the French edition (https://books.openedition. org/pulg/437). The English version is The Political Dimension of Aristotle's Ethics, trans. Jan Edward Garrett (Albany, NY: State University of New York Press, 1993), which I have cited in the text as PDAE. For Aristotle's texts, I have used Ross's translation of the Nicomachean Ethics (NE) and Lord's translation of the Politics (Pol.), occasionally consulting others. All Greek text is from the Oxford Classical Text editions of Aristotle's works (1988 and 1986, respectively).

2 He is more sceptical elsewhere - see, for instance, Bodéüs, "La Recherche Politique" - that the concluding passage of the Nicomachean Ethics leads directly to the Politics we possess. The passage, as he understands it, is less a "programme" than a reflection on the proper use of the study of constitutions; our Politics offers but an "echo" of that more robust study.

3 See Bodéüs, "Law and the Regime in Aristotle," henceforth $L R A$ in the text, which he calls a "complementary piece[]" to the book's argument in the author's preface to the English translation (PDAE, ix). 
connected and indeed interdependent. ${ }^{4}$ Despite its moments of "exhortation" to virtue $(P D A E, 60)$, Aristotle's study of ethics aims primarily to provide an account of human flourishing that can guide lawgivers. ${ }^{5}$ His study of politics discusses the institutional arrangements conducive to that flourishing. The philosopher's role is not to improve people by teaching them directly nor by giving laws but rather to help "the lawgiver gain possession" of "general knowledge about the human good" and "knowledge of the best political or constitutional rules" so that true principles about the good can be "taught — or to put it more precisely — inculcated by the lawgiver." Aristotle's political science is thus inherently practical, and it is "the political nature of the enterprise which unites the discourses of the Ethics and Politics" (PDAE, 39).

Precisely because "the human good is the end of politics," the happiness of the individual and the city "depends on the capacities of the politicians." The lawgiver's work is so important because virtue depends on proper habituation, particularly in youth, and this habituation in turn depends on the laws of a city requiring it. In short, no one - or, if we want to allow for some divine dispensation, almost no one - will become virtuous absent political order. ${ }^{6}$ To be sure, these virtuous habits inculcated by regimes are not virtue in the fullest sense, but they are the necessary precondition for virtue. Aristotle's treatises are accordingly "addressed to the politicians (primarily to the lawgivers)" who have "the ultimate task of defining coercive norms relating to the good" (PDAE, 3, 62).

Aristotle has high expectations for this audience of potential lawgivers. He demands of them both experience and the ability to follow reason rather than passions. Without "experience through involvement in public affairs," lawgivers will struggle to "judg[e] the quality of the laws" $(P D A E, 57)$. Perhaps more importantly, without that experience, aspiring lawgivers may be tempted

4 Following Bodéüs's example, I will refer more to the Nicomachean than the Eudemian Ethics, insofar as it displays more clearly "the political perspective of Aristotelian teaching" (PDAE, 5).

5 Others have identified the Ethics as the source for an "ethical science," a guide for the individual who seeks to be happy (a view summarized and critiqued by Bodéüs $P D A E, 39-42)$. A more plausible alternative is that the Ethics is at least in part "a phenomenology ... of human moral action," that is, a description of "how ethical phenomena present themselves in our experience of human conduct" (Sokolowski, "Honor, Anger, and Belittlement in Aristotle's Ethics," p. 221; a fuller exploration is Sokolowski, Moral Action). Such an interpretation would, I think, support Bodéüs's contention that the lawgiver must understand the motivations of human beings (PDAE, 63).

6 Bodéüs acknowledges the possibility of "generous, well-born characters, who are truly enamored of the good," but even these are not guided by arguments except insofar as they are "already oriented towards the good" (PDAE, 52). 
by the promise of more precision than the subject matter allows. They will be unable to distinguish "a genuine political teaching," such as Aristotle's, "from the rhetorical teaching of the Sophists" (PDAE, 112-113). Only one who has adequate experience can "check the propositions about politics which relate to his experience" (PDAE, 117) and is "capable of collecting with care and profit the fruits" of existing legislation (PDAE, 81). Comprehension of Aristotle's teaching about regimes is easier for those who have more experience, for such listeners are "able to test the discourse by reference to reality" (PDAE, 103-104). Aristotle's political teaching is therefore intended for "people sufficiently experienced both to understand the cogency of the propositions it contains and to express those propositions adequately in social reality (in the form of laws or precepts)" (PDAE, 67). In the same way that citizens require "virtuous habits," politicians - especially lawgivers - require experience in order to be taught (PDAE, 58).

And these "virtuous habits" are the basis of Aristotle's second expectation of his audience. He excludes those who have not been habituated to subordinate their desires to the demands of reason by means of law. One cannot become an Aristotelian lawgiver without having first learned to control his (or her) desires. Insofar as his lectures do not "contribute basically or directly to the moral education of those whom he addresses," Aristotle "supposes [his audience] already to be essentially virtuous," having been subject to "the compulsion of the laws," which is "indispensable" for acquiring the proper habits for listening to ethical discourses (PDAE, 4). Without this habituation, people will be unable to judge adequately what Aristotle says about virtue: "knowledge is no longer the condition of virtue, but virtue is the condition of knowledge," for "teaching does not create (moral) virtue in people but it permits prudent people to exercise better the virtue they already have" (PDAE, 51). It is the habitually repeated "virtuous action" that prepares a person "to grasp and acknowledge the truth of the principles which prompt his action" ( $P D A E, 36-37)$. And those who grasp that truth are then charged with instituting laws that help others acquire the necessary habits.

Yet there is another reason that a virtuous disposition is necessary for Aristotle's lawgivers. Without such a disposition, we could not be sure that lawgivers who knew the good would act on it. " "[T] he person who knows the good [must] possess the moral virtue which commits him to legislate in accord with what he knows the good to be," and thus "the lawgiver requires a moral education" both to be familiar with the good to be achieved through law but also because he must "decide to derive a law from the good." The "first quality" for Aristotle's audience is "the capacity, acquired by habituation, to act in accord with the law" rather than "one's own passions." This habituation brings with it "experience of

7 A similar argument about the necessity of ethical virtue for philosophy is found in Mara, "The Role of Philosophy in Aristotle's Political Science." 
actions characteristic of life," and it thus combines "a safeguard" for virtuous action with "the necessary condition" for judging adequately what is said about happiness (PDAE, 121-122).

The task of these lawgivers, having both adequate habituation toward virtue and sufficient experience in political matters, is to "establish laws that accord with right reason" so that the citizens of particular regimes can benefit from the same habituation and thus acquire, if not prudence, then at least "a permanent disposition to act in conformity with right reason" (PDAE, 38). Doing so properly "requires general knowledge concerning both constitutions and the human good," knowledge available in the Politics and Ethics respectively (PDAE, 39). According to Bodéüs's reading of Aristotle, "the teaching of ethics is addressed to the politician (lawgiver)" because "it is the task of politics to effectively ensure the morality and happiness of human beings" (PDAE, 69). For Aristotle, like Plato, "legislation is the tool required for the realization of the ends pursued by life in the city" (PDAE, 123, emphasis added). The requisite education should be construed broadly and begun early. We must "educate at first by habituation" before reason is strong enough to guide us $(P D A E, 54)$. Once accustomed to acting in accord with right reason, people can come to understand right reason for themselves and choose properly, but the basis on which they do so is those "dispositions ... acquired by having acted over a long time, either naturally or under the authority of [their] masters, according to a right reason which [they] did not possess" at first (PDAE, 36).

\section{The Limitations of Lawgiving}

I hope this is an adequate overview of Bodéüs's argument, for I want to pull on some of the threads therein to see whether they are loose or hold fast. In particular, I want to examine, first, the scarcity of potential lawgivers and the corresponding extension of that class to include parents and, second, the limitations imposed by reality on the attempt to educate citizens to virtue by means of the law.

Bodéüs is emphatic, as we have seen, that the discourses are addressed to the lawgiver. However, in some places, lawgivers are a particular class that is opposed, for instance, to ordinary politicians. The discourses are intended, he writes, "to instruct the politician and above all the politician par excellence, that is, the lawgiver" $(P D A E, 39)$. The lawgiver is one who has the power of "defining coercive norms relating to the good" (PDAE, 3, emphasis added). In other places, the lawgiver is a "quite broad" category that includes not only politicians but even "heads of households," who are responsible for enforcing the "same rules of conduct which are expressed in the laws" $(P D A E, 66) .{ }^{8}$ This

8 Curren, "Justice, Instruction, and the Good," offers a similarly broad reading of Aristotle's audience. The composition of Aristotle's audience in the ethical and political works is a recurring theme in the literature; see, most recently, Salkever, "Teaching the Questions." 
broader reading makes sense, insofar as "the actualization of the good in the city requires the cooperation of a master craftsman, the lawgiver, and subordinate laborers, the politicians in the narrow sense of the term" (PDAE, 65). If these "subordinate laborers" lacked adequate habituation or understanding, they might frustrate the attempt of the master craftsman to actualize the good. Nor would citizens who lacked habituation and understanding be capable of exercising the virtue of equity when called upon to supplement the laws that the lawgivers have made.

However, the broader reading of Aristotle's audience exacerbates a different problem: the scarcity of regimes that care for education — then, as now means a similar scarcity of people who are able to meet the requirements Bodéüs identifies, that is, anyone who has had the right kind of upbringing and the right kind of experience. Let me begin by acknowledging that Bodéüs has no illusions about the defective character of most existing political regimes or about the extent to which they fail to habituate their citizens toward virtue. As he notes, Aristotle consistently bemoans the lack of attention given to education in existing regimes. There is, to be sure, Sparta, which takes great care to habituate its young men; unfortunately, it habituates them not to virtue but to an overly spirited love of mastery (PDAE, 72). ${ }^{9}$

The famous passage in which everyone is said to agree that the lawgiver must prioritize the education of the young (Pol. 1337a11-12) is complicated by the fact that Aristotle asserts earlier in the Politics that education is not only neglected but in fact despised (ỏ $\lambda$ r $\omega \rho$ oṽ $\sigma$ ) by everyone (Pol. 1310a12-14). ${ }^{10}$ As a result, education is relegated to the private realm, in which parents educate their children as they see fit (Pol. 1337a24-26). Perhaps Aristotle means that everyone agrees about the necessity of education but does nothing about it - a typical danger of those things held in common, Aristotle observes in Book II (Pol. 1261b33-35). Or perhaps the widespread agreement about the importance of education exists only in the context of the regime according to prayer. In more common regimes, if there is to be anyone who can listen to and benefit from Aristotle's lectures, then I think we confront two options, neither of which is entirely consistent with Bodéüs's argument. We must hold that virtue can, in fact, be acquired in a regime that does not educate or educates incorrectly, either because habituation is not as necessary for virtue as Bodéüs claims or because laws are not required for habituation.

9 Aristotle specifically notes that the defective education of Spartans makes its senate dangerous to the city: the senators' authority, without audit, is unsafe because they have not been adequately educated (Pol. 1270b35-71a8).

10 Bodéüs refers to this passage twice. First, he refers to the part that highlights the necessity of educating people with a respect to the regime (PDAE, $166 \mathrm{n} 26)$. Second, he acknowledges that it complicates the claim about the importance of education without attempting to reconcile the two passages (PDAE, $196 \mathrm{n} \mathrm{1).}$ 
For the reasons Bodéüs himself outlines, the bulk of the Aristotelian corpus would weigh against the first of these options (e.g., Pol. 1332b10-11). There may, perhaps, be someone with a sufficiently divine nature (NE 1179b21-23) to be capable of acquiring virtue without habituation (though even these would not be truly prudent without education) but this is unreliable and, as with the city according to prayer, beyond our control. What I think Bodéüs suggests instead is that - according to the Nicomachean Ethics - in those regimes that do not care for education, "paternal authority" can at least partially substitute for the lack of "paternal wisdom." That is, there is the possibility that parents (primarily fathers) will align the education their children receive at home "with the principles of the laws which determine the development of the political community to which the children belong." To do this successfully requires that the heads of households know "the purpose of the laws" in order "to establish rules which are appropriate" for children: "legislative science," or nomothetike, "means the capacity to establish the rational norms which effectively govern human development," necessary not only for lawgivers but also for parents $(P D A E, 56)$. It is ultimately necessary for "the head of household to resemble a lawgiver" ( $P D A E, 73-74)$.

Bodéüs refers to this as "the solution of last resort, which one must adopt where the organization of an ideal educational system is neither applicable nor in force (i.e., in the great majority of cases)." He emphasizes that, for Aristotle, this is not a substitute, but "something to fall back on," that is, "the best realizable in a given situation" rather than "the best absolutely" ( $P D A E, 72-73)$. That is, Aristotle acknowledges the need for "a 'back-up' education for those cases in which the city is deficient in its duties" (PDAE, 77). This back-up, according to the text of the Nicomachean Ethics, is that an individual should "help his children and friends towards virtue" to the best of his ability (NE 1180a29-32).

Yet, given the acknowledged deficiencies of most existing regimes, the "solution of last resort" is usually going to be a first resort. Aristotle's lawgivers must be found not in regimes that habituate their citizens toward virtue but in households where parents (especially fathers) have properly discerned both the end toward which they should guide their children and the means by which to do so. But where, in turn, did these fathers acquire that ability? Given the difficulty of acquiring such knowledge for a regime, it is unlikely that fathers would acquire it - even less so, perhaps, if we demand of them that they reconcile a concern for virtue simply with a concern for the virtue appropriate to a particular regime. And given the lack of regimes that take education seriously, and the difficulty of parents doing so adequately, I am not sure that there would be many people capable of fulfilling the expectations Aristotle has for his audience. Because most regimes do not take an interest in the education of their citizens, it will be the task of parents to do so. This is, as Bodéüs acknowledges, a 'second-best' solution, but it is, as the Politics claims, almost certainly the more common solution. These facts would likely have been recognized by Aristotle and his purposes adjusted accordingly. The audience may contain the 
same people as the lawgiver broadly understood, but Aristotle addresses them less as lawgivers than as parents.

Yet most regimes do not merely fail to care adequately about education; they also tend to be less than fully just. In the absence of regimes that take an interest in the education of their citizens, the knowledge parents - and politicians will have about the human good and the means of achieving it is likely going to be affected by the regime in which they live. The classic statement of this is, of course, the discussion in Books VIII and IX of Plato's Republic, but I think it is echoed in Aristotle's own work. Regimes, after all, recognize and reward those who share their conception of justice, even when that conception of justice is partial. ${ }^{11}$ The partial views of justice held by oligarchs and democrats reflect mistaken views about the purpose of the regime; on their view, it exists not for the sake of the good life but for the accumulation of wealth or the preservation of freedom (cf. Pol. 1280a7 ff., 1301a25 ff.). Aristotle acknowledges that education might be common to all, but it can still result in making citizens lovers of wealth or of honour (Pol. 1266b34-38), the very things that he identifies as contributing to revolutions (Pol. 1302a31-32, 38-39).

Whatever parental advice can do to foster virtuous habits, it will struggle against the competing tendencies of a defective regime. This seems especially true of democratic regimes, as most democratic citizens think (however erroneously) that freedom involves living as one wishes (Pol. 1310a25-35, 1317b11-13). Ironically, these are the regimes in which most people might be able to acquire the political experience that Bodéüs finds necessary to learn from the Aristotelian discourses.

In general, Bodéüs claims, Aristotle holds that an audience must have "a sufficient familiarity with the facts of life" in order to judge his analysis $(P D A E, 98)$. But these facts will be different, and perceived differently, in different regimes: one who is committed to oligarchy may look differently at extremes of wealth distribution than one who is committed to democracy and differently still from one who transcends particular regimes entirely. Even if one concedes that education is principally about virtue, "not everyone honors the same virtue, so it is reasonable to expect them to differ as well in regard to the training in it" (Pol. 1337b1-3). Experience, in short, is always experience within a particular regime, and it is not clear that the experience within a particular regime - especially the most common regimes of oligarchy and democracy (Pol. 1290a13-16) — provides the proper habituation for judging well Aristotle's broader truths about politics.

11 Peter Simpson argues that "anyone educated in the virtue proper to a deviant regime would have been educated in a part of the ability proper to the good man and to the best regime," insofar as "education in deviant justice" is not "education in simple injustice" but "a partial education in justice" (A Philosophical Commentary on the Politics of Aristotle, p. 255). The problem is that the "partial" justice might make it difficult to acknowledge another part of justice, as I discuss below. 
Perhaps understanding Aristotle's intention for his political discourses might become clearer if we had a better sense of what he intends the education fostered by the lawgiver to entail. After all, Aristotle complains that Phaleas properly identifies education as one of the means of unifying a city but does not specify what that education entails. He thus objects that "one ought to say what the education is to be" (Pol. 1266b34). Bodéüs does just that, although he distinguishes between two kinds of education. Education, in its deeper form, involves "the formation of the whole person," training citizens "to judge every subjectmatter" (PDAE, 116-117). This is a kind of "liberal education," which is "able to shape minds just as capable of correct judgments as the minds of experts" (PDAE, $107 \mathrm{ff} ., 109)$. It is the subject of the discussion in Books VII and VIII of the Politics. Yet, because of the "historical contingencies which often make impossible the realization of an ideal," education is often nothing more than the laws that habituate us to restrain our desires, lest citizens "live at the mercy of their passions" (PDAE, 119). Which of these kinds of education should the lawgiver foster?

\section{The Limited Purpose of the Law}

In Bodéüs's contribution to Essays on the Foundation of Aristotelian Political Science, he concludes that lawgivers primarily foster the second, limited purpose of education. The requisite habits encouraged by potential lawgivers reflect a concern for stability and law-abidingness more than human flourishing. These habits would be inculcated by most regimes less for the benefit and flourishing of their citizens than for the preservation of that regime. To foster the development of virtue in the fuller sense would then be a task not for lawgivers as much as for parents, friends, and teachers.

Bodéüs grounds his argument on what he calls "the principle of the constitutionality of the laws," the belief that the various laws of a regime should reflect the regime for which they are enacted $(L R A, 236)$. He cites Aristotle's statement in Book III: "it is evident that the laws must be established to suit the constitution." 12 To this extent, the chapter reflects the conclusion of his book, emphasizing the necessity for lawgivers to educate "the future citizens required by the political regime to which he belongs, given that each regime necessarily implies a particular type of citizen" $(P D A E, 123)$. Yet the principle of the constitutionality of the laws has a corollary, which Bodéüs does not incorporate adequately. According to Aristotle, "it is clear that those [laws] enacted in accordance with the correct regimes are necessarily just, and those in accordance with the deviant ones, not just" (Pol. 1282b10-13). Bodéüs argues that, by teaching citizens to act in accord with its demands rather than their passions,

12 He later appeals to another formulation, this time found in Book IV, that "laws should be enacted - and all are in fact enacted — with a view to the regimes, and not regimes with a view to the laws" (Pol. 1289a13-15, 239 n 16). See also PDAE, 196 n 2. 
the law habituates them to follow reason — or, as he puts it, to act in accord with the law is to act in accord with " $\lambda$ ó $\gamma \circ \varsigma$ " $(P D A E, 121)$. In deviant regimes, though, this contention is problematic.

To be sure, the conformity of the laws to the regime is one of the most important ways that a regime can endure, and the preservation of a regime is, in general, valuable for Aristotle. Bodéüs rightly observes that, for Aristotle, "every form of constitution has some value; and even if one has less than another, its preservation almost always appears to him as a good (or a lesser evil) in relation to the harm caused by a radical change in regime and the disruption this brings in customs" (LRA, 235-236).

Yet it is not clear that, as Bodéüs suggests, Aristotle's criticism of existing regimes in the second part of Book II of the Politics focuses only on "the adequacy of the institutions in place relative to the end that the regime pursues" and not on the end that those regimes pursue. The best regime would, of course, both pursue the highest end and have the appropriate institutions for doing so. Bodéüs claims, though, that "one is entitled to regard as relatively good" not only regimes that aim (however imperfectly) at the highest end but also those regimes "whose institutions are in accord with the principle of its constitution." Such regimes - even if they fall short of the best possible as well as the best simply - are able to endure once established (LRA, 237-238). What is important, then, is to identify those laws that "undermine constitutional principles" and "what is left out of the legislation, which risks damaging the integrity of the constitution" (LRA, 240).

I do not wish to deny that this is an important part of Aristotle's political science. The stability of regimes is important, and maintaining existing regimes, whatever their character, is clearly announced as a function of Aristotelian political science at the start of Book IV of the Politics: a statesman must know how "any given regime ... might arise initially and in what manner it might be preserved for the longest time once in existence" (Pol. 1288b28-30). This, though, is but one part of Aristotelian political science, which also must study the best regime simply, the best regime generally possible, and the best regime for a particular polis.

For Bodéüs, however, it is the preservation of existing regimes through what we might call a 'fit' between the regime and its laws that "will occupy Aristotle's attention." Insofar as achieving the best regime is, as Aristotle says, a matter of prayer, "the good most accessible to existing cities that desire improvement is to be found in the conformity of their laws to the principles of their respective constitutions" and not in a change of those principles. Bodéüs argues that Aristotle's account of Sparta, for instance, focuses less on the end of the Spartan regime - "its tendency to cultivate only military virtue" — and more on the "the disagreement, contradiction, or inconsistency" of its laws and institutions with this purpose (LRA, 238-239). More generally, he says, "the great lesson" of Book II is that lawgivers ought to "remedy the faults" of existing regimes in order to make these regimes last longer — not by changing their ends but by 
making the means conducive to the ends (LRA, 239-240). The survey of these regimes is intended not to guide our interpretation of Aristotle's political science but to reveal Sparta - as well as Crete and Carthage — as inadequate guides to political practice. It is, after all, the purpose of Book II to consider those poleis said to be well governed, as a necessary precursor to Aristotle's own investigation (Pol. 1260b27-32). Indeed, Bodéüs himself, at the end of his book, indicates that lawgivers must sometimes engage in more thoroughgoing critiques of the regimes in which they live. Some regimes are simply too far "from the principles which should ground a good regime," and in such cases the lawgiver's task is "modifying the principles," not the laws, of these regimes. The example he offers of a regime in need of such correction of its principles is none other than Sparta $(P D A E, 125)$.

What I want to suggest, however, is that Aristotle's failure to criticize the end of those cities discussed in Book II reflects the fact that their end is in fact one of which Aristotle, in general, approves: a mixture of oligarchy and democracy. ${ }^{13}$ Such a mixture is not the best regime simply, but it may be the best generally possible. His criticisms of Sparta, Crete, and Carthage highlight the inadequacies of their efforts to balance the competing claims of rich and poor. ${ }^{14}$ What Aristotle offers in subsequent books of the Politics is a more careful attempt to do the same thing, with a view toward establishing the mixed regime he calls 'polity' (Pol. 1279a38-39). To this extent, then, Aristotle does not criticize the end pursued by these cities, for it is one he shares, but rather the way they pursue it. It is by showing how their institutions fail to achieve the balance they seek that Aristotle opens up space for his own inquiry into polities. ${ }^{15}$

Aristotle first introduces polity as a mixed regime in the context of discussing Plato's Laws, observing that the regime therein "is intended to be neither democracy nor oligarchy, but the one midway between them which is called a

13 I have similar reservations about Bodéüs's claim that Aristotle suggests that "the principle" of Plato's Republic "is no doubt fine" but "the legislative arrangements" articulated will fail to achieve it (LRA, 242-243). Aristotle certainly criticizes the Socratic proposal for abolishing the family because it will not, in fact, promote the unity of the city (Pol. II.3) - but he also dwells, and does so first, on the problematic character of making unity the goal (II.2). In contrast to Bodéüs's assertion that the regime "is ideal in its principle," Aristotle notes specifically that "[ $\mathrm{t}]$ he cause of Socrates's going astray one should consider to be the incorrectness of his basic premise" (Pol. 1263b29-31). In the treatment of the Republic, it seems, the end of the regime and means to it are equally criticized.

14 See, for instance, Frank, A Democracy of Distinction, pp. 126-128.

15 As Mary Nichols observes, one of the central themes of the Politics is to show lawgivers how to move from various kinds of regimes to polities (Citizens and Statesmen, Chapter 3). 
polity; for it is based on those who have heavy arms" (Pol. 1265b26-29). ${ }^{16}$ This is how Aristotle himself will initially describe a polity (Pol. 1279b1-4). In the context of the Laws, Aristotle's criticism is primarily directed against those who praise this kind of regime too highly, but he also adds that the regime, as described, tends "to incline more toward oligarchy" (Pol. 1266a5-7).

The same defect is highlighted in the subsequent criticisms of Sparta, Crete, and Carthage. ${ }^{17}$ The failure of Lycurgus to establish laws governing the education of women has resulted in an inordinate love of wealth (Pol. $1269 \mathrm{~b} 19 \mathrm{ff}$.). Aristotle acknowledges that the fault is not wholly Lycurgus's: he attempted to order the women, but they resisted, "and he gave it up" (Pol. 1270a6-8). As a result, Sparta's laws have generally favoured the wealthy: even democratic institutions like the common messes are oligarchic, because the poor are unable to contribute and thus to participate in the regime (Pol. 1271a26-37). ${ }^{18}$ In the last paragraph of the chapter, where he finally raises the obvious objection to Sparta - its orientation toward conquest - Aristotle concludes by noting not the warlike nature of its citizens but rather their greed ( $\varphi$ เ 1271b16-17). Even when criticizing the Spartan focus on "warlike virtue" $(\pi \circ \lambda \varepsilon \mu \iota \kappa \eta v)$, it is not clear that Aristotle criticizes that as an end, since it is the basis of his own polity, so much as for mistaking that part of virtue for the entirety of virtue (Pol. 1271b3; cf. 1279b1-2).

The first thing Aristotle tells us about the Cretan constitution is that it is very close to the Spartan constitution (Pol. 1271b20). To be sure, he acknowledges that its common messes are more democratic, but he also highlights ways in which the regime is even more oligarchic, through its mode of selecting the

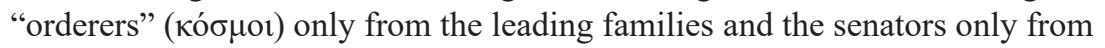
the orderers (Pol. 1272a28-36). In some cases, it is not the laws but rather individuals who rule, a system reminiscent of the worse forms of oligarchy (Pol. 1292b5-10). Aristotle praises Carthage more highly, but even this city is said to be very similar to Sparta. Its manner of election rewards merit, lending it an aristocratic dimension, but the deviations - specifically, according to Aristotle, from "aristocracy and polity" (Pol. 1273a4-5) - are effectively oligarchic (Pol. 1273a17, 22). Worst of all, wealth is more honoured than virtue,

16 It is typically ironic that Aristotle will later criticize Plato for omitting polity from the enumeration of regimes (Pol. 1293a39-b1) — not only because of its place in

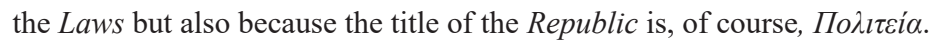

17 The criticisms of Phaleas and Hippodamus reflect well Bodéüs's contention that part of Aristotle's purpose in the political discourses is to disabuse his audience of any political teachings that are "conceived a priori" or claim "to be universally valid" (PDAE, 114-115).

18 Elsewhere, Aristotle identifies Sparta as a polity insofar as it can be spoken of as a democracy or oligarchy, arguing the common messes, like the common education, in Sparta are democratic elements amidst oligarchic ones (Pol. 1294b18-40). 
and because wealth is necessary to rule, it encourages officeholders to profit from ruling (Pol. 1273a37-b3). Aristotle's concluding judgement is a simple one: "the regime is oligarchic," and it avoids the factional strife characteristic of oligarchies by sending poorer citizens out to colonies (Pol. 1273b18-20). As Leslie Rubin concludes, the "common defect" of these three regimes is their "tendency toward oligarchy, more or less explicitly honoring the accumulation of individual wealth."19

Aristotle's criticism of these cities is thus directed not at their goal of balancing oligarchy and democracy but at the particular institutions by which they attempt to do so, which tilt what ought to be a polity toward an oligarchy. Aristotle warns about making use of devices that deceive the multitude (Pol. 1307b39-8a2), and he acknowledges that those regimes that enjoy greater popular support are more stable (Pol. 1302a13-15). Given this, I am sceptical that we can conclude that Aristotle is more concerned about the constitutionality of the laws, their fit with the particular regime, than he is about the kind of regime itself.

Bodéüs insists that for Aristotle "one cannot depend on anything other than the laws for maintaining over time a political regime" (LRA, 245). And, to bring us back to the project of The Political Dimensions of Aristotle's Ethics, the chief omission of legislation is an adequate emphasis on education - as noted in the cases of Plato, Phaleas, and Sparta. More specifically, what is required is that regimes educate their citizens to restrain their passions "under the pressure of the laws," a problem particularly pertinent for democracy, which is often grounded on the belief that freedom is nothing other than to live as they wish (LRA, 246). Bodéüs concludes the chapter by arguing, as he did in his book, that the Ethics and Politics are addressed to lawgivers so that they can educate citizens in order that they become happy. The purpose of the Politics is less to sketch an ideal regime than to offer lawgivers a variety of reflections that will help them in their task of working in imperfect conditions, in which the best may be nothing more than "the constitutional or legal rules that are the least removed from the good as is possible in that situation." The task is not wholescale reform but "a matter of supplementing or correcting the rules and usages currently existing, so as to confer on existing regimes the maximum possible in terms of goodness and duration" (LRA, 247). The regime sketched in Books VII and VIII is not within the lawgiver's power to bring about, but it still serves as "a model education" that can be used by lawgivers in imperfect regimes $(L R A, 248)$. And, more important, the limited educative function of the law — restraining our passions — is beneficial in itself as well as an essential first step in achieving that higher purpose of education: "the first quality of the educated person" is the ability, "acquired by habituation, to act in accord with

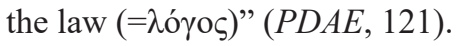

19 Rubin, America, Aristotle, and the Politics of a Middle Class, p. 20. 


\section{On Education in Deviant Regimes}

We must consider, then, the way in which education according to law operates in those deviant regimes - oligarchy and democracy — which, when mixed, result in a polity. In contrast to the polity, which Aristotle says rarely exists (Pol. 1293a39-b1), oligarchy and democracy were the regimes most common in Aristotle's time (Pol. 1290a13-16, 1301b39-2a1). ${ }^{20}$ Both of these regimes are defective and, as defective, tend toward instability. Indeed, the very cause of their degeneration is, Aristotle says, the mistaken nature of their opinions about justice: democrats behave factiously when they feel that they are not treated equally, whereas oligarchs bring about faction when they believe they lack the appropriate superiority (Pol. 1301a25-39). The factions introduced may lead to a change in those who have authority in the regime, a change in the kind of regime, or to a tightening or loosening of the regime - for instance, to make a democracy more or less democratic (Pol. 1301b4 ff.).

What Bodéüs suggests is that the lawgiver should ensure that the laws of a particular regime reflect the principles of that regime. Aristotle, however, warns against this: "to have everywhere an arrangement that is based simply on one or the other of these sorts of equality" — that is, the numerical equality of democracies or the proportional equality of oligarchies - "is a poor thing," because a regime based on one kind of equality will be short-lived (Pol. 1302a2-5). This is particularly true, he says, when it comes to educating citizens: citizens ought to be educated with a view toward their regimes, to be sure - "if the laws are popular, in a popular spirit, if oligarchic, in an oligarchic spirit." ${ }^{21}$ However, Aristotle says, to "be educated relative to the regime is not to do the things that oligarchs or those who want democracy enjoy" but rather to do "the things by which the former will be able to run an oligarchy and the latter to have a regime that is run democratically." In the existing oligarchies and democracies, however, "the opposite of what is advantageous" is done: oligarchs concentrate power until the poor revolt, and in democracies the opinion of the multitude takes precedence, reflecting a sense of freedom as "doing whatever one wants." This, Aristotle says, "is a poor thing," for it destroys democracy (Pol. 1310a12-36). ${ }^{22}$

What is needed, in short, is an education that, rather than taking the principles of a regime too far, keeps them within appropriate boundaries. As Eugene Garver writes, "Education in harmony with a constitution is education in moderation, in becoming a moderate democrat or oligarch. This education orients

20 That these are the most common regimes is not accidental but rather reflects the inevitable existence of rich and poor parts in every city. Whereas farmers may also be soldiers, the rich can never also be poor and vice versa (Pol. 1296a22-32).

21 Aristotle earlier said that this was also true of women and children (Pol. 1260b15-16).

22 The passage is referenced ( $L R A, 236 \mathrm{n} 8)$, but exclusively on the need to educate "in the spirit of the regime" rather than the potential tensions in doing so. 
the citizen toward ruling democratically or oligarchically, instead of living democratically or oligarchically, and therefore education in harmony with the constitution means becoming a fully politicized being." 23

On this reading, the problem for defective regimes is less laws that are inconsistent with the regime than laws that are too consistent with the regime. ${ }^{24}$ Deviant constitutions, according to Aristotle, overlook the necessity of moving toward the mean. Instead, they "pull the regime to an extreme" and adopt institutions, and presumably laws, that destroy the regime because they foster the conflict between the two economic classes that exist in the city (Pol. 1309b18$10 \mathrm{a} 1)$. When it comes to the most common regimes of Aristotle's time, the deviant regimes of oligarchy and democracy, it seems that what is necessary is less to adapt the laws to the regime than to ensure the laws depart from the principle of the regime in order to avoid taking it to the extreme.

David Keyt thus describes the education appropriate to these regimes as one that moderates both kinds of regimes: "educating in harmony with democracy should cultivate an understanding of democracy, should counter the excesses rabid democrats are prone to, and should promote good relations with the rich," and vice versa with oligarchy. ${ }^{25}$ Insofar as the legislation that educates young democrats and oligarchs moderates them, the objection of Richard Kraut that political education in defective regimes is good for "the political system," but not "good for children," is misguided. ${ }^{26}$

Perhaps this moderating tendency is what Bodéüs means by the responsibility of lawgivers to secure the constitutionality of the laws via education, but on the basis of the works under consideration here, that is not clear. Even if so, to persuade democratic citizens to adopt oligarchic — or at least less democratic — institutions may well require that these citizens be educated

23 Garver, Aristotle's Politics, p. 152. Garver argues that the tension between these goals indicates a disjunction between the two discourses: "If the Ethics is about how to be happy, the Politics is about how to be a political animal. Being a political animal is as much a full-time job as being virtuous is, and as difficult."

24 Thomas Pangle finds the tendency of regimes to become too much of themselves a reason to re-open the question of whether kingship might be the best regime (Aristotle's Teaching in the Politics, p. 210).

25 Keyt, Aristotle: Politics Books V and VI, p. 140.

26 Kraut, Aristotle: Politics Books VII and VIII, p. 169. W.L. Newman makes a similar objection to the idea of political education in "a tyranny or an extreme oligarchy or extreme democracy." He fears that Aristotle's emphasis on virtue relative to the constitution would require subordinating one's "conscience to the maintenance of the constitution" (The Politics of Aristotle, III.502). The answer, as sketched above, would be: yes, but the successful maintenance of the constitution requires following not the first advice Aristotle offers to tyrants (Pol. 1313a34-1314a29) but the second (Pol. 1314a29-15b10). 
by the lawgiver through teaching about the necessity of doing so, rather than merely being habituated to obey the laws.

More important, it is not clear that education plays a significant role in a mixed regime. Bodéüs identifies early in the chapter the centrality of "what one may call the mixed regime" to Aristotle's political thought, not because of its own merits but because of the way it tends "to guarantee the duration of fundamental political institutions." As Bodéüs himself notes, though, the stability of this regime is often due less to its form of regime than to "the factors ensuring its stability" (LRA, 237). This is evident in Aristotle's analysis of Sparta, Crete, and Carthage, which reveal the profound limitations of lawgiving. Lycurgus was unable to persuade the Spartan women to adopt his legislation. Aristotle ascribes the Cretan laws to Minos; even if we were to take this at face value, he warns that "most ancient things are less fully articulated than newer things," an implicit criticism of a reliance on the ancestral or divine (Pol. 1271b20-32). Its stability is due less to its institutions, divinely ordered or not, than to its location (Pol. 1272b16-17). And, in discussing Carthage, Aristotle does not even identify the lawgiver, although the anonymous figure is criticized for making the regime more oligarchic than aristocratic. Mary Nichols thus concludes that the story of these allegedly best regimes is less one of careful design than the power of chance. ${ }^{27}$

In a mixed regime, then, stability arises largely from external factors - among them chance - and less from the education of citizens. Indeed, precisely because of its mixed character, it is hard to envision such a regime taking an active interest in the education of its citizens insofar as it is pulled in two different directions. In arguing for the necessity of public education, Aristotle notes that education ought to be the same for all because the polis itself has but one goal (Pol. 1337a21-27). But the mixed regime has not one but two ends. Moreover, Aristotle explains that democracy reflects the opinion that those who are equally free ought to be equal in all things, whereas oligarchy reflects the opinion that those who are superior in wealth ought to be superior in all things (Pol. 1301a2535 ). It is hard to envision an education that would satisfy both of these parts of the mixed regime (cf. Rep. 554bc). As Catherine Zuckert notes, in the "best regime generally possible," a "compromise" between the two basic economic classes would "approximate the common good." Because it is grounded in a compromise rather than a principle, this regime would have "no explicit or intentional moral education undertaken by the government or the regime as such." 28

27 Nichols, Citizens and Statesman, pp. 45-46. See also Lockwood, "Politics II."

28 Zuckert, "Aristotelian Virtue Ethics and Modern Liberal Democracy," p. 89. Zuckert argues that modern liberal democracies, insofar as they avoid educating citizens toward virtue, reflect this mixed regime and accordingly emphasize the importance of private teaching about "what it means to be a good person or character," employing "examples drawn from history, literature, and film" (p. 91). 
The task of prudent lawgivers in such a regime may therefore be less to educate its citizens - which would, perhaps, require moving it in one direction or the other - than to ensure that the social and material conditions of that city endure and preserve the mixture. Aristotle suggests as much in discussing the causes of constitutional change, identifying "disproportionate growth" in one of the parts as a possible cause against which lawgivers must be wary (Pol. 1302b33-3a13). And it is the prevalence of a middle class, neither poor nor rich, that has the most to do with preserving a mixed regime (Pol. $1295 \mathrm{~b} 1 \mathrm{ff}$., 1304a38-b4). Aristotle thinks it is likely that polities will eventually become oligarchic or democratic when either the rich or poor in a city increase in power and pull the constitution toward one of the extremes; a large middle class, however, "dispels" the factions that bring about revolutions (Pol. 1307a20-27, 1308b28-31).

\section{Political Philosophy and the Problems of Politics}

Aristotle is not without resources to offer a lawgiver who wishes to establish a polity on firmer ground or to moderate the tendencies of democracies and oligarchies. These resources come to light as part of what Aristotle, in his only use of the term, calls "political philosophy," that is, the attempt to discern "equality in what sort of things" is appropriate to political communities (Pol. 1282b21-23). Political life is characterized by disputes about a basic question: who should rule? There is a variety of claimants. Some would claim to rule on the basis of ancestry, others on the basis of wealth. A greater number would claim to rule on the basis of free birth, while a smaller number might claim to rule - if they would claim to rule at all (cf. Pol. 1301a39-40, Rep. 520d-21b) - on the basis of virtue or knowledge. It is difficult to resolve these claims in a politically satisfactory way, as people's beliefs are reflective, at least in part, of their own status. On such a reading, the best we might hope for is an accommodation of the various claims much in the way Machiavelli presents the Roman republic in his Discourses on Livy or some form of a Rawlsian modus vivendi.

By turning to political philosophy as a means of investigating the conflicts between those who believe they ought to rule, Aristotle not only makes it possible to reconcile some of the various claims but also models that higher purpose of the city by inviting citizens to live well — that is, by taking part in a conversation about what is just, good, and advantageous (Pol. 1253a14-18), rather than simply pursuing wealth or pleasure or honour. Such a conversation can, and perhaps must, lead to an answer or compromise among the contenders, but it can also elevate the understanding of the various claimants as they see the limitations of their own claims as well as the merits of the claims of their rivals.

Political philosophy thus increases the possibility of a regime that is balanced between oligarchy and democracy by making clear to each side the partial, or incomplete, nature of its opinion about justice. It highlights the specific end of the political community as living well, rather than merely living, 
which subordinates the pursuit of wealth or freedom and thus qualifies the claims of rich and poor to rule. In so doing, it facilitates the establishment of a polity as well as the moderation of the democratic and oligarchic spirits necessary for a true political education with respect to the regime. The political philosopher shows the non-instrumental reasons that each regime's principle requires moderation. The political philosopher, however, has this effect through his teaching — a kind of education more like the "liberal," or "model," variant found in the city according to prayer in Books VII and VIII than the habituation characteristic of most cities. Is there anything that might dispose an audience in the regimes of polity, oligarchy, and democracy to accept the political philosopher's argument even without fully understanding it?

Insofar as Aristotle laments our tendency to make judgements that reflect our own interests, ${ }^{29}$ it might well be the case that those in the middle class, readiest to obey reason, are more likely to see the truth of Aristotle's account and thus to prefer a regime that balances the competing claims of rich and poor and maybe even those of the virtuous. Indeed, Aristotle's argument in favour of a large middle class includes an observation that "the best lawgivers" have come from this class; he includes Solon, Lycurgus, Charondas, and others (Pol. 1296a18-21). This observation seems to conflict with the overarching theme of Bodéüs's book: what made these lawgivers valuable was not experience in politics, nor having been raised in a regime that took an interest in habituating citizens toward virtue, but rather being part of an economic class that has a modicum of economic goods, "is readiest to obey reason," and is capable of friendship and ruling and being ruled in turn (Pol. 1295b1-34). Aristotle explicitly connects the account of the middle class constitution to what has been said in the Ethics about the way virtue is a mean (Pol. 1295a34-b1). ${ }^{30}$

If this is true, perhaps the chief responsibility of the lawgiver is to, as contemporary politicians say, grow the middle class. A small middle class, Aristotle says, is one of the reasons that democracy and oligarchy are so prevalent (Pol. 1295b39$6 a 3,1296 a 22-27)$. And if the growth of the middle class is the chief responsibility of lawgivers, then perhaps they would be better served by the apocryphal Oeconomica than the Ethics. In such a scenario, the support of citizens for the mixed regime may require more than the right kind of laws; in such a regime, education requires making citizens aware of the limitations of the political principles they affirm, a task better suited to the political philosopher than to the lawgiver. If this be a provocative - and tentative - conclusion, it is the fruit of engaging with the provocative, thoughtful, and immensely valuable work of Richard Bodéüs.

29 Aristotle states twice in seven lines that the inability to think seriously about justice stems from the tendency of people to make judgements based on their own interests (Pol. 1280a14-21).

30 The importance of the middle class is emphasized by, inter alia, Nichols, Citizens and Statesmen, and Rubin, America, Aristotle, and the Politics of a Middle Class. 
Acknowledgements: This paper was originally presented at the 2018 meeting of the Northeast Political Science Association. I am grateful to Thornton Lockwood for organizing the panels, inviting me to participate, and for his generous feedback on the various drafts of this manuscript. I am also grateful to Richard Bodéüs and the other panelists, as well as to Daniel Schillinger and Richard Dagger, for their comments on an earlier version of this work, and to the anonymous reviewers of the manuscript.

\section{References}

Aristotle

1986 Politica. Ed. W.D. Ross. Oxford: Oxford University Press.

Aristotle

1988 Ethica Nichomachea. Ed. I. Bywater. Oxford: Oxford University Press.

Aristotle

2009 Nicomachean Ethics. Trans. David Ross. Rev. Lesley Brown. New York: Oxford World Classics.

Aristotle

2013 The Politics. Trans. Carnes Lord. Chicago, IL: University of Chicago Press, $2^{\text {nd }}$ ed.

Bodéüs, Richard

1982 Le Philosophe et la Cité: Recherches sur les rapports entre morale et politique dans la pensée de Aristote. Paris : Les Belles Lettres.

Bodéüs, Richard

1983 "La Recherche Politique d'Apres le «Programme» de l'Ethique à Nicomaque d'Aristote." Les Ètudes Classiques 51 (1): 23-33.

Bodéüs, Richard

1991 "Law and the Regime in Aristotle," in Essays on the Foundation of Aristotelian Political Science, edited by Carnes Lord and David K. O'Connor. Berkeley, CA: University of California Press, pp. 234-248.

Bodéüs, Richard

1993 The Political Dimensions of Aristotle's Ethics. Trans. Jan Edward Garrett. Albany, NY: State University of New York Press.

Curren, Randall R.

1993 "Justice, Instruction, and the Good: The Case for Public Education in Aristotle and Plato's Laws: Part I." Studies in Philosophy and Education 11 (4): 293-311.

Frank, Jill

2005 A Democracy of Distinction: Aristotle and the Work of Politics. Chicago, IL: University of Chicago Press.

Garver, Eugene

2011 Aristotle's Politics: Living Well, Living Together. Chicago, IL: University of Chicago Press. 
50 Dialogue

Keyt, David

1999 Aristotle: Politics Books V and VI. Oxford: Clarendon Press.

Kraut, Richard

1997 Aristotle: Politics Books VII and VIII. Oxford: Clarendon Press.

Lockwood, Thornton C.

2015 "Politics II: Political Critique, Political Theorizing, Political Innovation," in Aristotle's Politics: A Critical Guide, edited by Thornton Lockwood and Thanassis Samaras. New York: Cambridge University Press, pp. 64-83.

Mara, Gerald M.

1987 “The Role of Philosophy in Aristotle's Political Science." Polity 19 (3): $375-340$.

Newman, W.L.

1950 The Politics of Aristotle. Oxford: Oxford University Press, 4 vols.

Nichols, Mary P.

1992 Citizens and Statesmen: A Study of Aristotle's Politics. Lanham, MD: Rowman and Littlefield.

Pangle, Thomas L.

2013 Aristotle's Teaching in the Politics. Chicago, IL: University of Chicago Press.

Rubin, Leslie G.

2018 America, Aristotle, and the Politics of a Middle Class. Waco, TX: Baylor University Press.

Salkever, Stephen

2007 "Teaching the Questions: Aristotle's Philosophical Pedagogy in the Nicomachean Ethics and the Politics." Review of Politics 69 (2): 192-214.

Simpson, Peter L. Phillips

1998 A Philosophical Commentary on the Politics of Aristotle. Chapel Hill, NC: University of North Carolina Press.

Sokolowski, Robert

2014 "Honor, Anger, and Belittlement in Aristotle's Ethics." Studia Gilsoniana 3: $221-240$.

Sokolowski, Robert

2017 Moral Action: A Phenomenological Study. Washington, DC: The Catholic University of America Press.

Zuckert, Catherine H.

2014 "Aristotelian Virtue Ethics and Modern Liberal Democracy." Review of Metaphysics 68 (1): 61-91. 